CURRENT RESEARCH JOURNAL OF PHILOLOGICAL SCIENCES

(ISSN -2767-3758)

VOLUME 03 ISSUE 01 Pages: 79-81

SJIF IMPACT FACTOR (2021: 5 . 823)

OCLC - 1242423883 METADATA IF - 6.925

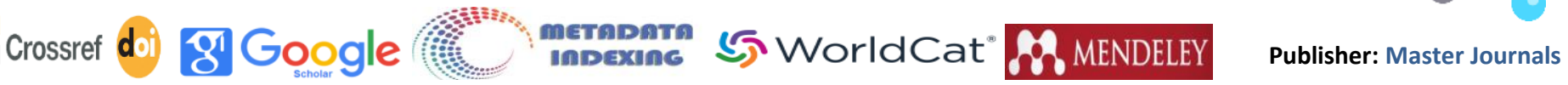

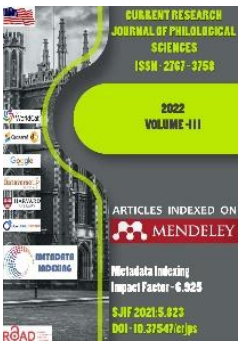

Journal Website: https://masterjournals. com/index.php/crips

Copyright: Original content from this work may be used under the terms of the creative commons attributes 4.0 licence.
Research Article

\section{THE USE OF IRONY IN THE ARTISTIC DISCOURSE}

Submission Date: January 11, 2022, Accepted Date: January 21, 2022, Published Date: January 31, 2022

Crossref doi: https://doi.org/10.37547/philological-crjps-03-01-13

\section{Alisher Abdupattayevich Parmonov}

Lecturer Of The Department Of Interfaculty Of Foreign Languages Kokand State Pedagogical Institute Named After Mukimi, Uzbekistan

\title{
ABSTRACT
}

This article describes the philosophical-logical, linguistic-pragmatic, semantic-stylistic, comparative-typological aspects of irony in discourse, and discusses many types of research in the linguistic literature and the means of their application in practice. It has been studied what groups they can be divided into in the field of science.

\section{KEYWORDS}

Lrony, comic irony, humorous irony, satirical irony, artistic discourse, ironic practice, realization of irony, dominance of artistic image, satire.

\section{INTRODUCTION}

The word irony comes from the Greek word eironea means to take oneself unknowingly, to pretend not to understand oneself, to deliberately show simplicity. The irony is used in the sense of deliberately supporting the judgment being criticized and secretly affirming the antithesis without explicitly stating it.
There are 3 types of irony, depending on the size of the critical potential expressed in the irony:

- comic irony;

- humorous irony;

- satirical irony. 


\section{CURRENT RESEARCH JOURNAL OF PHILOLOGICAL SCIENCES}

(ISSN -2767-3758)

VOLUME 03 ISSUE 01 Pages: 79-81

SJIF IMPACT FACTOR (2021: 5. 823)

OCLC - 1242423883 METADATA IF - 6.925

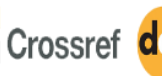

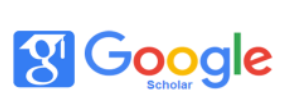

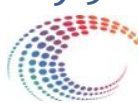

METDDETh

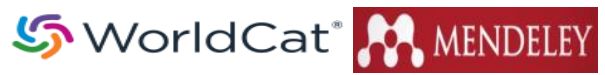

Publisher: Master Journals

In comic irony, denial is more than the meaning of affirmation.

In humorous irony, there is more to a positive attitude towards the thesis.

In a satirical irony, the speaker strongly criticizes the thesis he supposedly supports, simply laughing at it.

In our opinion, the use of irony in scientific statements in the social sciences and humanities (philosophy, history, political science, logic, sociology, psychology, philology, pedagogy) and even in theoretical linguistics is growing significantly.

\section{MATERIALS AND METHODS}

Theoretical research created in the $X X$ and $X X I$ centuries is characterized by the fact that the total and percentage of comic, humorous and satirical irony is higher than in previous centuries.

Explaining the relative and comparative progress of the use of irony in the above disciplines in connection with the implementation of this article in the material of artistic discourse, we see that there is an unlimited opportunity and need for the use of irony in artistic discourse.

Interest in the conceptual apparatus and principles of irony is felt not only in philosophy, but also in the sciences that study the laws of human cognitive activity, including cognitivism, cognitive linguistics. As the focus of irony has recently shifted more to the results of critical thinking, it is becoming more and more relevant to identify and understand the role of irony in knowing the world.

At this point, the following issues seem to be very relevant in theory. These are:
1) What is the ontological status of irony in determining the state of consciousness, to what extent;

2) What role does irony play in the learning process;

3) What functions does the practice of irony, or the realization of irony, perform;

4) What are the features of philosophical irony;

5) Why in the development of modern theoretical, social sciences and humanities, irony is becoming a hallmark.

The study of irony in world science in the XX-XXI centuries is characterized by the exchange of methodologies and the study of cognitive mechanisms in the human mind, in the naming process, research on the strategies of the creation of irony and their general laws and differences in different languages is currently relevant. Finding a scientifically based solution to these problems is about creating a "linguistic image" of the world by humans, solving many problems and issues related to the definition of language and the role of human in knowing the world.

There is a lot of research in the linguistic literature on the types of irony and the means of applying them in practice. We can divide them into the following groups in this scientific direction:

1) Irony as an aesthetic category was studied in the dissertation of V.M. Pivoev [1].

2) Irony as a historical category is considered in the scientific researches of R.M.Gabitova, P.P.Gaydenko, T.T.Gaydukova, A.F.Losev, V.P.Shestakov [2].

3) The work on the view of cinema as the dominant feature of the artistic image was carried out in the research of N.Ya. Berkovsky, V.V. Vanslov, I.Slavbo, M.M. Bakhtin [3]. 
CURRENT RESEARCH JOURNAL OF PHILOLOGICAL SCIENCES

(ISSN -2767-3758)

VOLUME 03 ISSUE 01 Pages: 79-81

SJIF IMPACT FACTOR (2021: 5 . 823)

OCLC - 1242423883 METADATA IF - 6.925

4) Irony is characterized as a defining tool of modern thinking. (P.Sloterdays, I.V.Cherdentsev, D.K.Myukke, E.Knoss).

5) Characterization of irony as a philosophical category researched in the works of F.Shlegel, F.Novalis, K.V.F.Zolger, G.V.F.Gegel, L.Wittgenstein, J.Derrida, S.Kerkegor, F.Nietzsche, E.I. Kononenko.

6) The problem of perception of irony by social and personal consciousness studied by A. Mueller, K. V. Zoliger, A. Bergson, V.S. .Lakatos, J.Lipovetski, D.Lungina, H.M.Motroshipova, V.Podoroga, M.Polani, R.Rorti, A.E.Sopovev, I.Todorov, S.Tulmin, P.Feyerabend, F.Fritof, M. Foucault, Y. Heyzingas [4].

7) The role of irony in the theory of literature in the research of V.V. Bychkov, N.B. Mankovsky, A.V. Gulyga, L.S. Sysoeva, T.I. Susleva, M.S. Kharitonova, O.V. Solodovnikov is widely studied [5].

8) The study of irony from a cultural point of view is focused on the research of V.M. Pivoev, V.P. Tugarinov, A.Ya. Khapsirokov, A.A. Ivsen, V.A. Vasilenko, M.S. Kagan and others [6].

9) We follow the study of the role and importance of irony in satire and humor in the research of G.N. Pospelov, Yu. Borev and others [7].

10) We observe the problems of irony in connection with the literature of the period in the works of V.Vanslov, A.Losev, V.Shestakov, N.Ya.Berkovsky, A.Bosarov [7].

11) We see the study of cinema as a separate modular type in the works of N. Fray and V. Tyupa [8].

\section{CONCLUSION}

In Uzbek linguistics and literature, no special research has been conducted on irony. We can mention only the dissertation of M.I. Sheralieva, articles of $\mathrm{H}$. Normatov and A. Otaboev and some other works on this issue.

\section{REFERENCES}

1. Philosophy and methodology of science, V.M.Pivoyev.

2. Philosophy, R.M.Gabitova.

3. Articles and lectures on foreign literature (collection), N.Ya, Berkovsky

4. Experience with direct data of consciousness, A.Bergson.

5. Aesthetics, V.V. Bychkov.

6. Questions of methodology and poetics: a collection of articles, G. N. Pospelov.

7. Aesthetics of romanticism, V.Vanslov

8. Philosophy, N.Fray. 